Canada's Telecommunications Policy Environment

Citation:

Middleton, C. (2011). Canada's Telecommunications Policy Environment.

Telecommunications Journal of Australia. (61:4). pp. 69.1-69.14.

Link to the Telecommunications Journal of Australia:

http://telsoc.org/journal 


\title{
CANADA'S TELECOMMUNICATIONS POLICY ENVIRONMENT
}

\author{
Catherine Middleton \\ Ryerson University
}

\begin{abstract}
This paper provides an overview of the telecommunications policy environment in Canada. Like Milner's (2009) article on New Zealand, this paper offers insights on international approaches to telecommunications policy. Canada's telecommunications history reveals a mix of private and public sector investment in regionally-based service providers. Canada did not have a single, publicly owned telecommunications carrier as was the case in Australia. Liberalisation of the telecommunications marketplace encouraged the development of competing infrastructures, with cable companies (traditionally focused on broadcasting distribution) and telephone companies now both providing wireline and wireless, voice, Internet and television services. Competition for wireline services remains regionally based, while wireless providers compete nationally.
\end{abstract}

\begin{abstract}
Although competition is intense, the broadband and wireless markets are highly concentrated. Competition in these markets has not resulted in extensive consumer choice, low prices or innovative services. Most Canadian consumers have access to broadband connectivity, but uptake rates now lag other OECD countries, for services that are slower and more expensive than those available in many other locations. Mobile phone penetration in Canada is on par with that of developing nations. The paper explores the characteristics of Canada's telecommunication markets, discusses the policy environment and notes that government has not offered a vision of a digital future for Canada.
\end{abstract}

\section{INTRODUCTION}

This paper provides an overview of the telecommunications policy environment in Canada. Like Milner's (2009) article on New Zealand, this paper offers insights on international approaches to telecommunications policy. Canada's telecommunications history reveals a mix of private and public sector investment in regionally-based service providers. Canada did not have a single, publicly owned telecommunications carrier as was the case in Australia. Liberalisation of the telecommunications marketplace encouraged the development of competing infrastructures, with cable companies (traditionally focused on broadcasting distribution) and telephone companies now both providing wireline and wireless, voice, Internet and television services. Competition for wireline services remains regionally based, while wireless providers compete nationally.

Although competition is intense, the broadband and wireless markets are highly concentrated. Competition in these markets has not resulted in extensive consumer choice, low prices or innovative services. Most Canadian consumers have access to broadband connectivity, but uptake rates now lag other OECD countries, for services that are slower and more expensive than those available in many other locations. Mobile phone penetration in Canada is on par with that of developing nations. The paper explores the characteristics of Canada's telecommunication markets, discusses the policy environment and notes that government has not offered a vision of a digital future for Canada. 


\section{A BRIEF HISTORY OF TELECOMMUNICATIONS IN CANADA ${ }^{1}$}

The Bell Telephone Company of Canada was established in 1880. Three members of the board were from the American Bell Telephone Company and by 1882, almost $50 \%$ of the shares in the Canadian company were held by American Bell (beginning a history of American investment in the Canadian telecommunications sector that continued for the next century). The Bell Telephone Company of Canada had a monopoly across the country, with exclusive rights to construction on railway rights of way. 'Unprofitable rural territories' were ceded to local companies (Babe 1990, 75), with Bell consolidating its operations in the provinces of Ontario and Quebec. Over time, regionally based telephone companies emerged, some competing with Bell (which often refused to provide long distance connections to these competitors). Some regional companies were held privately (including British Columbia Telephone, later named BC Tel, which was controlled by US company GTE). Others were publicly owned, either by municipalities or by provincial governments. For much of the twentieth century, the telephone companies in Alberta, Saskatchewan and Manitoba were owned by the provincial governments.

Canada's telephone companies operated as regional monopolies, supervised by federal, provincial or municipal agencies. Most telephone calls between regions were transmitted through the United States until the 1931 formation of the TransCanada Telephone System (later named Telecom Canada and then Stentor). This alliance of Canada's largest telephone companies coordinated telephone service across the country, and represented their common interests in regulatory discussions. International service was provided by the Canadian Overseas Telecommunications Corporation, a crown (government owned) corporation and the Canadian member of Intelsat, renamed Teleglobe Canada in 1975. Teleglobe was privatised in 1987. In 1998, rules for routing international traffic were eliminated, removing Teleglobe's monopoly on international calls, and allowing domestic calls once again to be routed through the US (Babe 1990; Industry Canada 2005).

In the 1960s several groups proposed the construction of a satellite service, to provide telecommunications and television services across the country. Telesat Canada was created in 1969, owned by the federal government, telecommunications companies and private investors. The company was expected to operate on a commercial basis, but was established as a 'carrier's carrier,' meaning it could only provide services to existing terrestrial carriers. This approach removed the possibility of competition between the satellite carrier and terrestrial carriers (who owned a large share of Telesat), and the terrestrial carriers had little incentive to shift traffic off their terrestrial networks onto the domestic satellite service. Telesat was not profitable, and when additional capital was needed to upgrade its satellites it was proposed that the company become a member of the TransCanada Telephone System (TCTS). This suggestion was rejected by the regulator on the grounds that it was not in the public interest, but the federal government overruled the regulator and allowed Telesat to become part of TCTS. The federal government sold its shares in Telesat in 1992, and Telesat's monopoly on domestic and trans-border satellite carriage ended in 2000.

\section{REGULATION AND MARKET LIBERALISATION}

In 1976, the jurisdiction of the Canadian broadcasting regulator was expanded to include federally regulated telecommunications companies. The Canadian Radio-television and Telecommunications Commission (CRTC) is an independent organisation that reports to federal parliament through the Minister of Canadian Heritage. The CRTC's mandate is 'to ensure that both the broadcasting and telecommunications systems serve the Canadian public' (Canadian Radio-Television and Telecommunications Commission 2009a). Policy decisions are made to achieve the objectives of the 1991 Broadcasting Act (Canada 1991) and the 1993 Telecommunications Act (Canada 1993).

Before 1993, the telecommunications sector was governed under the 1906 Railway Act. The 1993 Telecommunications Act recognised that telecommunications have 'an essential role in 
the maintenance of Canada's identity and sovereignty' and laid out federal legislation to govern the telecommunications sector. The act set policy objectives to develop a telecommunications system that would 'safeguard, enrich and strengthen the social and economic fabric of Canada and its regions.' This system should render 'reliable and affordable telecommunications services of high quality accessible to Canadians in both urban and rural areas in all regions of Canada.' Telecommunications policy should enhance 'efficiency and competitiveness' of the Canadian telecommunication sector, promote 'ownership and control of Canadian carriers by Canadians,' and encourage the use of Canadian transmission facilities. The Act also notes that telecommunications policy should aim to stimulate research, development and innovation around the provision of telecommunication services in Canada, 'respond to the economic and social requirements of users of telecommunications services' and 'contribute to the protection of the privacy of persons' (Canada 1993, Section 7).

By encouraging 'increased reliance on market forces for the provision of telecommunications services' and requiring that policy must ensure that 'regulation, where required, is efficient and effective,' the 1993 Telecommunications Act continued the liberalisation of the Canadian telecommunications sector begun in the late 1970s when the CRTC allowed competition in the data services market. Decisions in the 1980s and 1990s opened the market to further competition. In 1992 the long distance telephone market was opened to competition, and in 1997 competition was introduced in local telecommunications markets. The CRTC forbears from regulating telecommunications markets that it considers to be competitive, including retail Internet services and mobile services (Canadian Radio-Television and Telecommunications Commission 2011b). Wholesale Internet access markets are regulated.

In 2006, as a result of an extensive review of telecommunications policy in Canada (Telecommunications Policy Review Panel 2006), the federal government issued a policy directive to the CRTC further entrenching the role of the market in delivering telecommunication services. This policy directive requires the CRTC to:

I) rely on market forces to the maximum extent feasible as the means of achieving the telecommunications policy objectives, and

II) when relying on regulation, use measures that are efficient and proportionate to their purpose and that interfere with the operation of competitive market forces to the minimum extent necessary to meet the policy objectives (Governor in Council 2006).

While policy is to rely on market forces, Canada's telecommunications market is not open to foreign competitors. The 1993 Telecommunications Act imposed strict Canadian ownership requirements for operating a telecommunications carrier in Canada. $80 \%$ of a carrier's voting shares must be held by Canadians (for holding companies investing in carriers two-thirds of their voting shares must be held by Canadians), and at least $80 \%$ of the members of the board of directors must be Canadian (Canada 1994). These are among the most restrictive foreign ownership rules in the OECD (Organisation for Economic Co-Operation and Development 2011b). Reviews of telecommunications and competition policy have called for more liberalised foreign investment rules for the telecommunications sector in Canada (Competition Policy Review Panel 2008; Telecommunications Policy Review Panel 2006). Foreign ownership restrictions on satellite carriers were removed in 2010 (Clement 2010). The current federal government has indicated that further questions of foreign ownership will 'receive renewed government scrutiny' (Government of Canada 2010, 17). A consultation on foreign investment in the Canadian telecoms sector closed in July 2010 (Industry Canada 2010b) but no additional changes to the current policies have been initiated.

\section{STRATEGIC DIRECTION}

Canada does not have a digital economy strategy or a national broadband plan. In 2009, then Industry Minister Tony Clement announced that the government of Canada intended to 'regain its leadership position in the digital economy' (Clement 2009). In 2010, the government held a consultation on the Digital Economy, receiving more than 250 submissions from organisations and individuals. Priority areas for strategic action include the 
development of a 'world-class digital infrastructure' and ensuring that all Canadians have 'digital skills' (Government of Canada 2010). It was anticipated that a Digital Economy strategy would be released in early 2011, but an election and change of Minister have delayed this release. As such, Canada has no explicit strategic approach for further development of Canada's telecommunications infrastructure, leaving it to market forces to determine the nature of services on offer to Canadians.

\section{TELECOMMUNICATIONS IN CANADA TODAY}

The telecommunications market in Canada today is dominated by large telecommunications and cable companies operating in regional markets to provide telephone and Internet services. These companies also operate as broadcast distribution undertakings to provide television services, and some also own television stations and/or other media assets. ${ }^{\underline{3}}$ In the telecommunications market (comprising Internet, wireless, wireline voice and data and private line services) five incumbent telephone companies (telcos) generate about two-thirds of total revenues (Canadian Radio-Television and Telecommunications Commission 2011b). The western incumbent telco Telus was formed through the privatisation of Alberta Government Telephones and a later merger with $\mathrm{BC}$ Tel. The incumbent in the province of Saskatchewan, SaskTel, remains government owned. In Manitoba, Manitoba Telephone Systems was privatised and later acquired Allstream to become MTS Allstream. Bell Canada remains the dominant carrier in Ontario and Quebec. Bell Canada Enterprises also controls Bell Aliant, formed by the merger of the four provincial incumbents in eastern Canada. The telco incumbents compete with each other for business customers, but each serves its their own geographic region in the residential wireline voice, television and fixed line Internet market. The telcos offer television services using satellite or IPTV (Internet Protocol Television).

Canada's cable companies (cablecos) were among the first in the world to offer hybrid-fibre coax (HFC) broadband services, beginning in late 1996 (Lie 2003). Cable companies also offer voice over IP (VoIP) home telephone service to compete with the wireline service offered by telcos. The top five cable companies generate about $30 \%$ of telecommunications revenues (Canadian Radio-Television and Telecommunications Commission 2011b). Like their telco competitors, the cable companies are regionally based. Shaw operates primarily in Western Canada, Rogers in Ontario, Cogeco in Ontario and Quebec, Videotron in Quebec, and Eastlink in Eastern Canada. Cable companies do not compete with each other in providing residential television, Internet or VoIP home phone service.

Competition in the Canadian residential broadband market is primarily between the incumbent telephone company and the cable company in each geographic region (facilitiesbased competition) in what has been labeled as the 'battle for the broadband home.' For instance, in Western Canada, telco Telus competes with cableco Shaw. In Ontario, telco Bell competes with cablecos Rogers and Cogeco, but in Quebec Bell competes with Videotron. Bell, Rogers and Telus dominate the national wireless market. About half of Canadian households bundle their local phone service with internet, mobile, and/or television. In so doing, households make a choice as to whether they will obtain their telecommunications and television services from a cableco or from a telco. Households that do not bundle their services may choose to combine services from a wireless carrier, local telco or cableco, and from resellers. Only about $2 \%$ of telecommunications revenues are generated by the top five resellers. The resellers typically offer Internet and wireline phone services. In 2010 Canadian cablecos generated two-thirds of their revenues from telecommunications services, while telcos generated less than $7 \%$ of their revenues from broadcasting services (Canadian RadioTelevision and Telecommunications Commission 2011b).

The two sections below describe Canada's broadband and wireless markets, discussing the nature of services on offer and efforts by governments to encourage infrastructure development and increase competition within markets. 


\section{BROADBAND}

The broadband market in Canada is characterised by competition between the regional telco and the regional cableco. Most Canadian households have a choice of DSL or cable broadband; $96 \%$ of households have access to at least one fixed line service. $70 \%$ of Canadian households subscribed to a broadband service offering download speeds of $1.5 \mathrm{Mbps}$ or higher in 2010, with just over 50\% subscribing to speeds greater than 5 Mbps. In 2010, 56\% of households purchased their broadband from a cableco (some of which offer DOCSIS 3.0 speeds), and 38\% from an incumbent telco (typically offering DSL, although VDSL/fibre-tothe-node service is now available in some parts of the country) (Canadian Radio-Television and Telecommunications Commission 2011b).

Wireless broadband services have not been widely adopted. As of December 2010, Canada was ranked 24th in the OECD for wireless broadband subscriptions. Most of Canada's wireless broadband subscribers access this service on their smartphones, rather than through standalone data plans (

Canadians were early adopters of wireline broadband (second only to Korea among OECD countries until 2004), but in the past few years Canada's position as a broadband leader has eroded. OECD data show other countries overtaking Canada in terms of broadband adoption, while Canada's prices remain relatively high (Organisation for Economic Co-Operation and Development 2011a). Akamai's quarterly reports show faster Internet speeds in many other countries (Akamai 2011).

In 2010, a House of Commons committee investigating foreign ownership in the telecommunications sector concluded:

The recent performance of the Canadian telecommunications industry is, on the whole, unsatisfactory. In particular, the Committee considers that the relatively low level of wireless phone penetration and the disappointing progression of broadband penetration in recent years are symptomatic that all is not well in Canada's telecommunications industry (in terms of pricing, services offered, and the competitive environment in general). (Standing Committee on Industry Science and Technology 2010, 41)

The 2010 Berkman Center for Internet and Society report on international broadband policy described Canada as a 'weak performer,' noting that a pricing study demonstrated the highest prices and lowest speeds were on offer in countries like the US and Canada where facilitiesbased competition was dominant (Benkler et al. 2010). Canadian broadband providers disputed these findings. (Goldberg 2010)

Most Canadian residential broadband plans are subject to download caps. For instance, entry level plans offered by Bell and Rogers in Ontario have a 2 gigabyte per month download limit. Customers who exceed their bandwidth cap on these entry level plans are charged an additional usage charge of $\$ 2.50$ or $\$ 5$ per gigabyte. ${ }^{4}$ Additionally, many of the incumbent telcos and cablecos throttle customers' broadband connections. This practice, to manage network congestion, is allowed by the CRTC's policy on Internet traffic management practices (Canadian Radio-Television and Telecommunications Commission 2009b) but at least one ISP has been found to be violating this policy in its application of bandwidth throttling (Openmedia.Ca 2011).

Although Canada's regulatory environment requires that telcos and cablecos provide competitors with access to their facilities on a wholesale basis, independent providers only serve about $6 \%$ of the retail market (Canadian Radio-Television and Telecommunications Commission 2011b). The Berkman Center report describes Canada's unbundling policies as 'weakly implemented.' van Gorp and Middleton (2010) conclude that Canada's facilities-based competitive environment has not resulted in effective competition (defined by the ACCC as allowing competitors to hold 'a reasonably sustainable market position', Australian Competition \& Consumer Commission 2009). 
It is difficult to get information on the Canadian wholesale broadband market. Data on the number of telco exchanges where competitors have installed their own equipment is not readily available, nor is there general information on the numbers of unbundled lines in service. Evidence provided in CRTC hearings suggests that the most common form of wholesale broadband is what is known as the 'aggregated ADSL access service.' This service allows a competitor (access seeker) to connect to customers' premises by establishing a single point of interface with an incumbent telco (Canadian Radio-Television and Telecommunications Commission 2008). For instance, a competitor could serve any customer on the Bell network in Ontario and Quebec by connecting to the Bell network in a single location. This avoids the cost of co-locating in multiple exchanges, but means that the competitor cannot manage the speed of the connection or otherwise differentiate the services on offer. Canada's cablecos are also required to allow third party Internet access (TPIA) to their broadband networks. For many years, competitors found it difficult to establish wholesale relationships with cablecos, but this arrangement is becoming more common now (in part because of regulatory changes to facilitate access).

The relationship between competitors and the incumbents from whom they buy wholesale services is often contentious. It is difficult for competitors to compete with incumbents when providing service over the incumbents' networks (see Middleton and Van Gorp 2009, for discussion of some of the challenges). Incumbents argue that competitors should build their own networks if they are unhappy with the services available to them on a wholesale basis. Competitors do want to invest in their own infrastructure, but need to establish sufficient revenues and a strong customer base first, by selling services over incumbents' networks. The incumbents' terms are often not favourable to their wholesale customers. For instance, incumbents can impose traffic management practices on their wholesale networks (bandwidth throttling), restricting speeds at certain times of day. It took several years for competitors to get access to the same speed tiers that were being offered by incumbents to their own retail customers (competitors only had access to slower speeds). There is a current dispute over billing practices in the wholesale market, with competitors seeking flexibility to price their services in ways that would differentiate them from the incumbents. $\frac{5}{5}$

As noted, many Canadian households buy their telecommunication services in bundles. Competitors are able to offer VoIP telephone services and Internet access. CRTC regulations do not require telcos or cablecos to offer wholesale access to multicasting (to deliver IPTV), noting that the wholesale access regime is designed to provide access to Internet services (Canadian Radio-Television and Telecommunications Commission 2010). While Internet and television services are different, competitors' Internet offerings may be less attractive when not bundled with television or wireless services, meaning that the decision to exclude wholesale access to multicasting does have an impact on the competitiveness of the retail Internet access market.

The CRTC has not been successful in establishing a competitive wholesale market for broadband services. Regulatory decisions that would encourage competition have been appealed repeatedly (delaying their implementation), reversed or sent back to the regulator (by government) for reconsideration. The incumbent telco/cableco duopoly does offer most Canadians a choice of copper (DSL/VDSL) or HFC broadband connectivity, but at comparatively high prices for bandwidth capped plans. Telcos and cablecos do compete intensely with each other, resulting in quite different competitive conditions in various regions across the country. There are some competitors attempting to challenge the duopoly to deliver more internationally competitive, faster, affordable, innovative broadband services to Canadians, but with just $6 \%$ market share their impact has been limited.

Canada has no national broadband plan to articulate a vision for the sort of broadband connectivity that should be available to Canadians in the future. There are no specific plans for extending or improving connectivity to Canada's unserved and underserved rural and remote areas, or for encouraging improvements to broadband offerings in urban areas. Earlier recommendations for the development of a national broadband infrastructure have not been pursued. A 2001 taskforce recommended federal investment of $\$ 6$ billion to extend broadband connectivity to all Canadians by 2004 . While noting that broadband speeds would need to 
evolve over time, this taskforce recommended that the network should provide symmetrical 1.5 Mbps connectivity as its initial target speed (National Broadband Task Force 2001). The 2006 Telecommunications Policy Review Panel also called for additional federal investment in broadband, recommending the development of a ubiquitous Canadian access network to deliver on the policy objectives of providing affordable access to telecommunications services in all parts of the country (Telecommunications Policy Review Panel 2006).

As part of an economic stimulus package in 2009, the federal government committed $\$ 225$ million for expansion of broadband connectivity in rural and remote regions, noting that $22 \%$ of rural households did not have broadband connectivity (Industry Canada 2009). Funding was not available in all regions of the country however, as provincial or territorial programs were already in place to extend broadband connectivity to households and businesses in Nova Scotia, New Brunswick, Prince Edward Island, Saskatchewan, Yukon and eastern Ontario. In eligible regions, federal funding would provide up to $50 \%$ of the project cost, with the expectation that the remainder of the funding would come from other levels of government or the private sector. Additional federal funds were available from other sources for First Nations (aboriginal) communities. Eight years after Canada's National Broadband Taskforce recommended defining broadband in symmetrical terms, the target speeds for the 2009 project were $1.5 \mathrm{Mbps}$ for downloading and $384 \mathrm{kbps}$ for uploading (i.e., a much lower upload speed than recommended in 2001), and the project did not aim to connect all Canadians.

The 2009 program has funded some additional broadband capacity in the country, but at the end of 2011 there is still no master plan in place to guide further development of broadband networks in Canada. Satellite broadband service should be able to reach all Canadians, but even with the recent launch of a satellite that will support faster speeds, prices are higher than in urban areas (Xplornet 2011). The Province of Nova Scotia is considered by the federal government to offer $100 \%$ connectivity, but does so at speeds of $1.5 \mathrm{Mbps}$, using fixed wireless technologies in rural and remote locations (Province of Nova Scotia 2011). In contrast, a project in eastern Ontario funded by three levels of government is aiming to provide connectivity at speeds of $10 \mathrm{Mbps}$ to $85 \%$ of that region (Eastern Ontario Regional Network 2011), with a completion date of 2013. In the province of Alberta, the 'SuperNet' offers next generation fibre connectivity to more than 400 communities (connecting schools, government offices and health care facilities, Alberta SuperNet 2010), but fast residential broadband is not available in all communities.

The CRTC recently noted that continued rollout of broadband infrastructure should be guided by market forces (as per the policy directive it was given in 2006), supplemented by targeted government funding for public/private partnerships to extend connectivity where the private sector will not invest. The Commission concluded that 'it would not be appropriate at this time to establish a funding mechanism to subsidise the deployment of broadband Internet access services,' but did decide that it would be in the public interest to set target speeds for broadband access. The proposed target speeds are $5 \mathrm{Mbps}$ download and $1 \mathrm{Mbps}$ upload (actual speeds), to be available to all Canadians by the end of 2015 (Canadian RadioTelevision and Telecommunications Commission 2011d). There are no targets for next generation broadband capacity, and no nationwide plan for network upgrades.

\section{WIRELESS}

The dominant national players in Canada's wireless market are Bell, Telus and Rogers. The national players also operate discount brands (Virgin, Koodo, Fido and Chatr). Some telcos offer wireless services on a regional basis (e.g. SaskTel, MTS Allstream) and there are a few mobile virtual network operators. $99 \%$ of the population has access to $2 \mathrm{G}$ or $3 \mathrm{G}$ service (which covers only $20 \%$ of the country's geographic area), and $97 \%$ are within the $4 \mathrm{G}$ network footprint. The three operators are now rolling out LTE (long term evolution) networks in Canada's major cities. Despite the ubiquity of mobile phone networks, mobile phone adoption in Canada is on par with developing nations, with about 70 subscriptions per 100 population (as compared to 101 per 100 in Australia). More than 100 countries have 
higher mobile phone penetration rates than Canada (International Telecommunication Union 2011).

OECD data show that Canadian mobile customers pay high prices for low and moderate usage levels (often twice as high as comparable services in Australia in 2009), and average revenue per user for Canadian mobile providers is among the highest in the OECD (Organisation for Economic Co-Operation and Development 2011b). Many Canadian mobile plans charge users for making long distance calls, and also for services like voicemail and call display. It is difficult for customers to switch providers as phones are typically sold locked to a specific network provider, and customers frequently sign three-year contracts.

An auction of AWS (Advanced Wireless Services, 1700 and $2100 \mathrm{MHz}$ bands) in 2008 had an explicit objective of increasing competition in the Canadian wireless market. Set asides were used to ensure that new entrants could obtain spectrum (Industry Canada 2010a). Cable companies Videotron and Shaw both purchased spectrum. Videotron now offers mobile service in its regional market, allowing for 'quadruple play' (wireline and wireless voice, Internet and television) bundling. Shaw recently decided not to build a cellular network, choosing instead to build out a Wi-Fi network in partnership with Cisco to meet anticipated demand for mobile data services (Shaw Communications and Cisco 2011).

Two other companies are building out national mobile networks using spectrum acquired in the 2008 auction. These companies are new entrants to the wireless industry in Canada, and do not offer wireline broadband, wireline voice or television services. WIND Mobile (part of the Globalive group) was the first to launch, in late 2009. Mobilicity launched in mid-2010. Both WIND and Mobilicity are building their networks across the country, starting in the major population centres. A third new entrant, Public Mobile, is currently offering service only in Toronto and Montreal. The CRTC reports that the new entrants' networks now reach $50 \%$ of the Canadian population (Canadian Radio-Television and Telecommunications

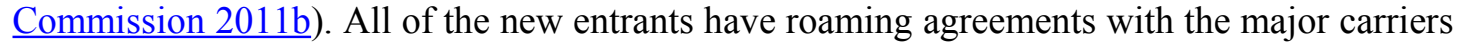
to provide connectivity across the country.

The new entrants are changing the market by offering lower pricing and shorter contracts, and it appears that they are having some impact in making the Canadian mobile services market more competitive. The new entrants are expected to have 5\% market share by the end of 2011 (Convergence Consulting Group 2011), a percentage that will likely increase as Canadians' current mobile phone contracts expire and they are free to switch providers.

The new entrants do face challenges however. They are competing against bundled services offered by the incumbent cablecos and telcos, and have limited brand recognition. Because the AWS bands are not widely used for mobile services the market for AWS devices is small. Popular phones like the iPhone are not available for AWS. US operator T-Mobile also uses AWS spectrum, and devices available to the Canadian operators were often first available in the US. Handsets that work on the major Canadian carriers' networks do not work on the new entrants' AWS networks.

New entrants have promoted fixed pricing in their services, but as in other countries there continue to be many complaints from Canadian mobile customers about wireless pricing and bill shock (Commissioner for Complaints for Telecommunications Services 2010; Janigan 2010). The Competition Bureau has powers to investigate anti-competitive practices including price fixing, abuse of dominant market position and deceptive marketing practices (Competition Bureau 2011). The Bureau published guidelines for investigating abuse of dominance in the telecommunications sector in 2008 (Competition Bureau 2008) and has taken action against telecommunications companies for misleading advertising of the price, speeds and quality of their services. There are also provincial initiatives in place (Quebec, Manitoba) or under consideration (Ontario) to amend consumer protection legislation to require plain language contracts and to reduce penalties for terminating contracts.

Foreign ownership restrictions have kept international wireless operators out of the Canadian market. ${ }^{6}$ Various reviews of the Canadian telecommunications market suggest that opening 
the wireless market to foreign competitors would offer benefits to Canadians. For instance, the 2006 Telecommunication Policy Review Panel noted that:

The major multinational wireless operators have brought significant new technology transfers, capital, marketing and management know-how to the U.S. and most other OECD countries - but they are not able to participate fully in Canadian markets. Based on the experience of other countries, it seems difficult to dispute that their presence would significantly improve the range, quality and pricing of wireless services available to Canadians. (Telecommunications Policy Review Panel 2006, p. 11-20).

The 2010 parliamentary committee report on ownership rules reached a similar conclusion, observing that 'foreign ownership restrictions disproportionally penalise new entrants and smaller players through their effect on the cost of capital; this in turn lowers the ability of new entrants and smaller players to pose a competitive threat to large incumbents' (Standing Committee on Industry Science and Technology 2010, p. 41). As noted earlier, the government has not yet responded to the consultation process initiated in mid-2010, leaving the question of changes to Canada's foreign ownership rules unresolved.

The foreign ownership question is germane to plans for auctioning the $700 \mathrm{MHz}$ spectrum band. Analogue broadcasting was switched off in Canadian major centres on August 31, 2011 (Canadian Radio-Television and Telecommunications Commission 2011c) $)^{7}$ A consultation on the policy and technical framework for auctioning the $700 \mathrm{MHz}$ spectrum band freed by the digital television transition closed in February 2011. This spectrum will be allocated for the provision of 'commercial mobile systems,' with a view to encouraging 'the continued growth of wireless broadband, leading to lower prices and improved quality of service for end-users, as well as enhanced opportunities for innovation and investment' (Industry Canada 2010a, p. 2). No auction date or policy framework has yet been announced, but it is anticipated that the auction will take place in late 2012.

\section{DISCUSSION}

The Canadian government aspires to restore Canada's leadership position in the digital economy. The assessment of Canada's telecommunications markets offered here suggests that the current approach is unlikely to realise this objective. Specifically, although facilities-based competition in the broadband market has encouraged network rollout, the broadband services on offer across the country could be described as average (or as legal scholar Michael Geist suggested in 2009, 'not awful'). The broadband duopoly does not enable effective competition, and regulatory actions to open the market to further competition have not had the desired results. Efforts to increase competition and encourage innovation in the wireless market have been slow to take hold, and may explain Canada's lagging wireless uptake rates. The absence of international carriers in the Canadian market has likely hindered innovation.

Recent high-level meetings at the OECD and the ITU, and the work of the ITU/UNESCO Broadband Commission for Digital Development ${ }^{8}$, continue to advance the case for broadband as a fundamental driver of social and economic benefit. While the preferred model for broadband infrastructure development appears to be a market-driven one (OECD 2011a), the Canadian experience suggests that highly concentrated markets do not fully deliver the anticipated competitive outcomes of choice, affordability and innovation in broadband and wireless services.

The Canadian telecommunications market provides basic connectivity, but the focus of private sector providers is on building infrastructure and selling profitable services that make use of this infrastructure (for instance, the need to compete with the cable companies to deliver entertainment content is driving telco investment in next generation networks that support IPTV). The private sector does not appear to have a vision for the use of broadband networks as enablers of broader socio-economic benefit, as envisaged in ongoing discourses of e-health, e-learning, smart grids, and trans-sectoral services (Broadband Commission for Digital Development 2011). While the private sector can play a role in enabling such services, 
it is up to government to take the lead in articulating a vision for a broadband-enabled society, building on its recent public consultations and policy reviews.

The 2006 Telecommunications Policy Review Panel offered many recommendations for improving Canada's telecommunications policy environment. It suggested clearer articulation of the social objectives of telecommunications policy, and recommended making competition in the telecommunications market more efficient, strengthening the powers of the CRTC, enhancing the rights of telecommunications consumers and ensuring that all Canadians have access to affordable, reliable broadband services. These recommendations have not been incorporated into Canada's telecommunications policies. Inaction on the digital economy strategy, on the review of foreign ownership in the telecommunications sector, and on the development of a policy framework for the upcoming $700 \mathrm{MHz}$ spectrum auction suggest that Canada's quest for leadership in the digital economy is stalled. The spectrum auction is of enormous importance, as it will shape the mobile broadband market for the next generation. A vision of Canada's digital future is needed to guide the spectrum allocation. This broadband vision should be accompanied by a plan that charts a course for the development of next generation networks in Canada, outlines the opportunities for all Canadians to benefit from improved broadband connectivity and articulates concrete actions to encourage digital literacy and bridge the digital divide.

\section{CONCLUSION}

This paper offers a high level overview of the telecommunications policy environment in Canada. It describes a liberalised telecommunications market in which multiple providers compete in highly concentrated market segments. There is of course more complexity in this environment than can be conveyed in a brief paper, but the general conclusion is that, as compared to many other OECD markets, the Canadian telecommunications market delivers slower, more expensive broadband and more expensive wireless services.

The Canadian telecommunications market offers an interesting contrast to the Australian one. Differences between the two countries are stark, particularly regarding the provision of wireline broadband connectivity, and in the take-up of wireless broadband services. Canada's hands-off, market driven approach has fostered the development of two competing broadband infrastructures (very different from the approach now underway in Australia with the construction of the National Broadband Network). In Canada, similar services are offered on both platforms, meeting the basic connectivity needs of Canadians. Infrastructure upgrades are being driven by competition among private sector providers, with a particular focus on the delivery of television programming, rather than by a grand vision of broadband as public infrastructure that can boost national productivity, enhance health and educational outcomes, encourage social cohesion and better environmental outcomes (Australian Government 2011).

Despite various consultative processes to shape a digital economy strategy, there is no concrete vision of a broadband-enabled society in Canada. Unlike in Australia, the Canadian government has not taken a strong leadership role, nor has it committed to the development of next generation broadband infrastructure as a national priority, choosing instead to leave the shaping of the digital economy to the private sector. Time will tell whether one approach is better than the other.

\section{REFERENCES}

Akamai. 2011. 'The State of the Internet - 2nd Quarter 2011 Report'. Cambridge, MA: Akamai. 
Alberta SuperNet. 2010. 'What Does the SuperNet Do?'. Accessed 1 September 2010. Available from:

http://www.thealbertasupernet.com/what is the supernet/what does supernet do.html.

Australian Competition \& Consumer Commission. 2009. 'Fixed Services Review Declaration Inquiry for the ULLS, LSS, PSTN OA, PSTN TA, LCS and WLR: Final Decision'. Canberra: Commonwealth of Australia.

Australian Government. 2011. 'National Digital Economy Strategy - leveraging the National Broadband Network to Drive Australia's Digital Productivity'. Canberra: Department of Broadband, Communications and the Digital Economy.

Babe, Robert E. 1990. Telecommunications in Canada: Technology, Industry, and Government. Toronto: University of Toronto Press.

Benkler, Yochai; Faris, Robert; Gasser, Urs; Miyakawa, Laura; Schultze, Stephen. 2010. 'Next Generation Connectivity: A Review of Broadband Internet Transitions and Policy from around the World'. Cambridge, MA: Berkman Center for Internet \& Society, Harvard University.

Broadband Commission for Digital Development. 2011. 'Broadband: A Platform for Progress'. Geneva: ITU/UNESCO.

Canada. 1991. Broadcasting Act, S.C., 1991, C. 11. Ottawa: Minister of Justice.

Canada. 1993. Telecommunications Act, S.C., 1993, C. 38. Ottawa: Minister of Justice.

Canada. 1994. 'Canadian Telecommunications Common Carrier Ownership and Control Regulations'. Accessed 9 October 2011. Available from:

http://laws.justice.gc.ca/PDF/SOR-94-667.pdf.

Canadian Radio-Television and Telecommunications Commission. 2008. Telecom Decision CRTC 2008-17: Revised Regulatory Framework for Wholesale Services and Definition of Essential Service. http://www.crtc.gc.ca/eng/archive/2008/dt2008-17.htm.

Canadian Radio-Television and Telecommunications Commission. 2009a. 'About the CRTC'. Accessed 9 October 2011. Available from: http://www.crtc.gc.ca/eng/backgrnd/brochures/b29903.htm.

Canadian Radio-Television and Telecommunications Commission. 2009b. 'Telecom Regulatory Policy CRTC 2009-657: Review of the Internet Traffic Management Practices of Internet Service Providers'. Accessed 5 September 2011. Available from: http://www.crtc.gc.ca/eng/archive/2009/2009-657.htm.

Canadian Radio-Television and Telecommunications Commission. 2010. 'Telecom Decision CRTC 2010-632: Wholesale High-Speed Access Services Proceeding'. Accessed 3 September 2010. Available from: http://www.crtc.gc.ca/eng/archive/2010/2010632.htm.

Canadian Radio-Television and Telecommunications Commission. 2011a. 'Broadcasting Regulatory Policy CRTC 2011-601: Regulatory Framework Relating to Vertical Integration'. Accessed 25 October 2011. Available from: http://www.crtc.gc.ca/eng/archive/2011/2011-601.htm.

Canadian Radio-Television and Telecommunications Commission. 2011b. 'Communications Monitoring Report'. Ottawa: Canadian Radio-television and Telecommunications Commission.

Canadian Radio-Television and Telecommunications Commission. 2011c. 'On August 31, 2011, Canadian Local over-the-Air Television Stations Converted to Digital Television'. Accessed 30 October 2011. Available from: http://www.crtc.gc.ca/eng/info_sht/bdt14.htm.

Canadian Radio-Television and Telecommunications Commission. 2011d. 'Telecom Regulatory Policy CRTC 2011-291: Obligation to Serve and Other Matters'. Accessed 
20 August 2011. Available from: http://www.crtc.gc.ca/eng/archive/2011/2011291.htm.

Clement, Tony. 2009. 'Opening Remarks - Canada's Digital Economy: Moving Forward'. Industry Canada. Accessed August 30 2011. Available from: http://www.ic.gc.ca/eic/site/ecic-ceac.nsf/eng/gv00537.html.

Clement, Tony. 2010. 'Government Response to the Report of the Standing Committee on Industry, Science and Technology on Canada's Foreign Ownership Rules and Regulations in the Telecommunications Sector'. Accessed 24 October 2011. Available from: http://www.parl.gc.ca/HousePublications/Publication.aspx? DocId $=4690759 \&$ Language $=E \&$ Mode $=1 \&$ Parl $=40 \&$ Ses $=3$.

Commissioner for Complaints for Telecommunications Services. 2010. 'Annual Report 20092010: Talking Solutions and Getting Results'. Ottawa: CCTS.

Competition Bureau. 2008. 'Information Bulletin on the Abuse of Dominance Provisions as Applied to the Telecommunications Industry'. Accessed 9 October 2011. Available from: http://www.competitionbureau.gc.ca/eic/site/cb-bc.nsf/eng/02690.html.

Competition Bureau. 2011. 'Our Organization'. Accessed 9 October 2011. Available from: http://www.competitionbureau.gc.ca/eic/site/cb-bc.nsf/eng/h_00125.html.

Competition Policy Review Panel. 2008. 'Compete to Win - Final Report June 2008'. Ottawa: Public Works and Government Services Canada.

Convergence Consulting Group. 2011. 'Canadian Wireless 2009-2014: Assessing the Impact of New Entrants'.

Eastern Ontario Regional Network. 2011. 'Ontario's Largest Rural Broadband Network'. Accessed 25 October 2011. Available from: http://eorn.ca.

Federal Court of Appeal. 2011. 'Dockets: A-78-11 and a-79-11'. Accessed 26 October 2011. Available from: http://www.canadiancommunicationslaw.com/A-78-11\%20and\%20A79-11\%20Reasons $\% 20 \% 282 \% 29$.pdf.

Geist, Michael. 2009. 'ISP Funded Report Finds Canadian Broadband Isn't Awful'. Accessed 9 October 2009. Available from: http://www.michaelgeist.ca/content/view/4443/125/.

Goldberg, Mark. 2010. 'Berkman Broadband Study Got Basic Data Wrong'. Accessed 23 August 2010. Available from: http://mhgoldberg.com/blog/?p=3656.

Government of Canada. 2010. 'Improving Canada's Digital Advantage. Strategies for Sustainable Prosperity - consultation Paper on a Digital Economy Strategy for Canada'. Accessed 10 May 2010. Available from: http://de-en.gc.ca/wpcontent/uploads/2010/05/Consultation_Paper.pdf.

Governor in Council. 2006. 'Order Issuing a Direction to the CRTC on Implementing the Canadian Telecommunications Policy Objectives'. Accessed 19 March 2009. Available from: http://canadagazette.gc.ca/archives/p2/2006/2006-12-27/html/sor-dors355eng.html.

Industry Canada. 2005. 'Telecommunications Service in Canada: An Industry Overview'. Accessed 22 October 2011. Available from: http://www.ic.gc.ca/eic/site/smtgst.nsf/eng/sf05637.html.

Industry Canada. 2009. 'Broadband Canada: Connecting Rural Canadians - Application Guide'. Ottawa: Industry Canada.

Industry Canada. 2010a. 'Consultation on a Policy and Technical Framework for the $700 \mathrm{Mhz}$ Band and Aspects Related to Commercial Mobile Spectrum'. Ottawa: Industry Canada Spectrum Management and Telecommunications.

Industry Canada. 2010b. 'Opening Canada's Doors to Foreign Investment in Telecommunications: Options for Reform'. Ottawa: Spectrum Management and Telecommunications. 
Information Canada. 1971. 'Instant World: A Report on Telecommunications in Canada'. Ottawa: Telecommission Directing Committee.

International Telecommunication Union. 2011. 'Measuring the Information Society'. Geneva: International Telecommunication Union.

Janigan, Michael. 2010. 'Waiting for the Dream: The Consumer Case for Telecom Reform and Results-Based Regulation'. Ottawa: Public Interest Advocacy Centre.

Lie, Eric. 2003. 'Promoting Broadband: The Case of Canada'. Geneva: International Telecommunication Union.

Middleton, Catherine A; Van Gorp, Annemijn F. 2009. 'How Competitive Is the Canadian Residential Broadband Market? A Study of Canadian Internet Service Providers and Their Regulatory Environment'. Telecommunications Policy Research Conference; Arlington, VA.

Milner, Murray. 2009. 'Playing the Telecommunications Game in New Zealand: The Evolving Story of Telecommunications Public Policy in New Zealand'. Telecommunications Journal of Australia 59 (2): 26.1-26.17. Available from: http://tja.org.au/index.php/tja/article/view/112.

National Broadband Task Force. 2001. 'The New National Dream: Networking the Nation for Broadband Access'. Ottawa: Industry Canada.

OECD. 2011a. 'Communiqué on Principles for Internet Policy-Making - OECD High Level Meeting on the Internet Economy'. Paris: OECD.

OECD. 2011b. 'OECD Wireless Broadband Subscriptions Per 100 Inhabitants, by Technology, December 2010'. Accessed 3 September 2011. Available from: http://www.oecd.org/dataoecd/21/35/39574709.xls.

Openmedia.Ca. 2011. 'It's Official: Gamers Have Caught Rogers Violating Internet Openness Rules'. Accessed 30 October 2011. Available from: http://openmedia.ca/news/it $\% \mathrm{E} 2 \% 80 \% 99$ s-official-gamers-have-caught-rogers-violating-internet-openness-rules.

Organisation for Economic Co-Operation and Development. 2011a. 'OECD Broadband Portal'. Accessed 20 October 2011. Available from: www.oecd.org/sti/ict/broadband.

Organisation for Economic Co-Operation and Development. 2011b. OECD Communications Outlook 2011. Paris: OECD.

Pavri, Vera. 2009. 'What You Say Is What You Get: Policy Discourse and the Regulation of Canada's First Domestic Communications Satellite System'. Technology and Culture 50 (3): 569-585.

Province of Nova Scotia. 2011. 'Broadband for Rural Nova Scotia'. Accessed 11 November 2011. Available from: http://www.gov.ns.ca/econ/broadband/.

Shaw Communications; Cisco. 2011. 'Shaw and Cisco to Establish Extensive Wi-Fi Network in Western Canada'. Accessed 23 October 2011. Available from:

http://www.shaw.ca/uploadedFiles/Corporate/Media/Press_Releases/ShawCiscoSep12.p df.

Standing Committee on Industry Science and Technology. 2010. 'Canada's Foreign

Ownership Rules and Regulations in The Telecommunications Sector'. Ottawa: House of Commons Canada.

Taylor, Gregory. 2010. 'Shut-Off: The Digital Television Transition in the United States and Canada'. Canadian Journal of Communication 35 (1): 7-25.

Telecommunications Policy Review Panel. 2006. 'Telecommunications Policy Review Panel Final Report 2006'. Ottawa: Industry Canada. 
Van Gorp, Annemijn; Middleton, Catherine. 2010. 'The Impact of Facilities and ServiceBased Competition on Internet Services Provision in the Canadian Broadband Market'. Telematics and Informatics 27 (3): 217-230.

Wilson, Kevin G. 2000. Deregulating Telecommunications: U.S. And Canadian Telecommunications, 1840-1997. Lanham, Md.: Rowman \& Littlefield Publishers.

Winseck, Dwayne. 1997. 'Canadian Telecommunications: A History and Political Economy of Media Reconvergence'. Canadian Journal of Communication 22 (2): 217-260.

Xplornet. 2011. '4G Satellite Plans \& Pricing'. Accessed 25 October 2011. Available from: http://www.xplornet.com/SatPlans.aspx.

\section{ENDNOTES}

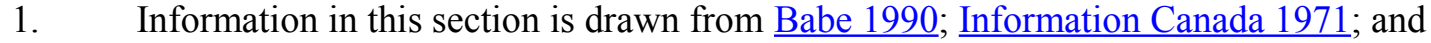
Winseck 1997.

2. See Industry Canada 2005; Information Canada 1971; Pavri 2009; and Wilson 2000, for more details on Telesat Canada.

3. The CRTC recently set out a regulatory framework for vertically integrated companies in the broadcasting and telecommunications sector (Canadian RadioTelevision and Telecommunications Commission 2011a).

4. All dollar amounts are Canadian dollars. In October 2011, $\$ 1$ Canadian $=\$ 0.94$ Australian.

5. Documents from CRTC hearings on Internet Traffic Management Practices (Telecom Public Notice CRTC 2008-19), Wholesale High-Speed Access Services (TNC CRTC 2009-261) and Usage Based Billing (TNC CRTC 2011-77) demonstrate the conditions imposed by incumbents on their wholesale customers. These conditions make it very difficult to develop innovative, competitive offerings when relying on wholesale access to incumbents' networks.

6. In 2009, the CRTC ruled that WIND Mobile's parent company Globalive did not comply with Canada's foreign ownership restrictions. This decision was overturned by the federal government but appealed to the Federal Court. The Federal Court then supported the CRTC's initial ruling, only to be overruled on appeal (Federal Court of Appeal 2011), settling the matter that WIND Mobile is eligible to provide services in Canada.

7. See Taylor 2010, for analysis of Canada's digital television transition.

8. http://www.broadbandcommission.org

Cite this article as: Middleton, Catherine. 2011. 'Canada's telecommunications policy environment'. Telecommunications Journal of Australia 61 (4): 69.1-69.14. Available from: http://tja.org.au. 